\title{
Morphological and Thermal Properties of Cellulose Nanofibrils Reinforced Epoxy Nanocomposites
}

\section{Morfološka i toplinska svojstva epoksidnih nanokompozita ojačanih celuloznim nanofibrilima}

\author{
Original scientific paper • Izvorni znanstveni rad \\ Received-prispjelo: 30. 1. 2014. \\ Accepted-prihvaćeno: 14. 1. 2015. \\ UDK: $630 * 812.14,630 * 813.13,630 * 824.321$ \\ doi:10.5552/drind.2015.1403
}

\begin{abstract}
Epoxy resins have gained attention as important adhesives because they are structurally stable, inert to most chemicals, and highly resistant to oxidation. Different particles can be added to adhesives to improve their properties. In this study, cellulose nanofibrils (CNFs), which have superior mechanical properties, were used as the reinforcing agent. Cellulose nanofibrils were added to epoxy in quantities of $1 \%, 2 \%$ and $3 \%$ by weight to prepare nanocomposites. Morphological characterization of the composites was done with scanning electron microscopy (SEM). Thermal properties of the nanocomposites were investigated with Thermogravimetric Analyzer (TGA/DTG) and Differential Scanning Calorimeter (DSC). SEM images showed that the cellulose nanofibrils were dispersed partially homogenous throughout the epoxy matrix for $1 \% \mathrm{CNF}$. However, it was observed that the cellulose nanofibrils were aggregated (especially for 2 and $3 \%$ CNFS) in some parts of the SEM images, and the ratios of the aggregated parts increased as the loading rate of the cellulose nanofibrils increased. The TGA curve showed that DTG and decomposition temperature of pure epoxy was higher than that of the nanocomposites. The DSC curve showed that the glass transition temperature $\left(T_{g}\right)$ value of pure epoxy was found to be similar with $T g$ of the nanocomposites.
\end{abstract}

Keywords: Epoxy nanocomposites, cellulose nanofibrils, morphological and thermal analysis

SAŽETAK • Epoksi smole smatraju se važnim ljepilima jer su strukturno stabilne, inertne na većinu kemikalija $i$ vrlo otporne na oksidaciju. Ljepilima se za poboljšanje njihovih svojstava mogu dodati različite čestice U ovom istraživanju, kao sredstvo za ojačanje kompozita upotrijebljeni su celulozni nanofibrili (CNFs), koji imaju izvrsna mehanička svojstva. Celulozni su nanofibrili dodani epoksi smoli u količini od 1,2 i 3 \% mase radi izrade nanokompozita. Morfološka karakterizacija kompozita napravljena je skenirajućim elektronskim mikroskopom (SEM). Toplinska svojstva nanokompozita istražena su termogravimetrijskim analizatorom (TGA/DTG) i diferencijalnim skenirajućim kalorimetrom (DSC). SEM slike pokazale su da su celulozni nanofibrili raspršeni djelomično homogeno u matrici od epoksidne smole s 1 \% CNFs-a. Međutim, uočeno je da su celulozni nanofibrili agregirani (pogotovo za 2 i $3 \%$ CNFs-a) u nekim dijelovima SEM slike, a udjel agregiranih dijelova povećava se s udjelom celuloznih nanofibrila. TGA krivulja pokazala je da su DTG i temperatura raspadanja čiste epoksi smole veće od

\footnotetext{
Author is assistant professor at Bartin University, Faculty of Forestry, Forest Industrial Engineering, Bartin, Turkey.

Autor je docent Sveučilišta u Bartinu, Fakultet šumarstva i industrijske prerade drva, Bartin, Turska.
} 
temperature raspadanja nanokompozita. DSC krivulja pokazala je da je temperatura staklastog prijelaza $\left(T_{g}\right)$ čiste epoksi smole slična vrijednosti $T_{g}$ za nanokompozite.

Ključne rijječi: epoksidni nanokompoziti, celulozni nanofibrili, morfološka i toplinska analiza

\section{INTRODUCTION}

1. UVOD

Generally, epoxy adhesives have been used because they have good physical properties and high bonding strength. Epoxies have many applications, ranging from electronic technologies to the development of new materials (Kozma and Olefjord, 1987). Their properties can be tailored for the desired end use, e.g., they can be filled or foamed, flexible or rigid, high or low modulus materials, a conductor or an insulator, a fire retardant, and resistant to chemicals. Epoxy systems basically contain two main components, i.e., the resin and a hardener. The hardener initiates the chemical reaction, which converts the epoxy resin into a solid material that has a crosslinked network of chains of molecules. Epoxies are said to be 'thermosetting' because, when they are cured, they are irreversibly rigid and relatively unchanged by heat. Curing of epoxies begins when a hardener is added. The curing of epoxy resins generally is an exothermic reaction, which causes the temperature of the process to increase (Petrie, 2006). Epoxies are used extensively in many applications to bond the substrates of different materials (Lapique and Redford, 2002). In recent years, it has been shown that the addition of nanoparticles and nanofibrils to adhesives is an economical and environmentally friendly way to improve the various properties of a polymer. Nano-sized materials have superior properties, such as increased chemical activities, increased aspect ratios, and enhanced physical properties (Auer and Frenkel, 2001). Thus, many researchers (Zhai et al., 2007; Masoodi et al., 2012) have shown important progress in obtaining significant improvements in performance, such as enhanced physical, mechanical, thermal, and surface properties, by mixing low concentrations of nanoparticles or nanofibrils with epoxy.

Cellulose nanofibrils (CNFs), which are natural fibrils that occur at the nano scale, were selected for use in producing nanocomposites. The cellulose chains are held together by hydrogen bonds between hydroxyl groups. Therefore, cellulose chains have high strength and stiffness. They have begun to receive additional attention as a reinforcement material because of reductions in the energy requirements for breaking down cellulose fibrils in nanofibrils (Siro and Plackett, 2010). Previous studies on reinforced epoxy, an adhesive that is not used extensively in the wood industry, showed that the addition of different fillers improved the toughness of the adhesive bond (Kinloch and Lee, 2003; Stewart et al., 2007).

In this study, cellulose nanofibrils were selected because of their sustainability, industrial ecology, eco-efficiency, inexpensive cost, green chemistry, and abundance in nature. Cellulose nanofibrils have a high reinforcing effect and can improve the properties of the matrix (Sain and Oksman, 2005). Epoxy was chosen as the matrix due to its good physical properties and excellent bonding strength. Thermal properties of the composites prepared with epoxy and cellulose nanofibrils at different loadings ( $1 \%, 2 \%$, and $3 \%$ by weight) were investigated with thermogravimetric analysis (TGA/ DTG) and differential scanning calorimeter (DSC). Morphological structure of the obtained composites was characterized with scanning electron microscopy (SEM).

\section{MATERIALS AND METHODS 2. MATERIJALI I METODE}

Cellulose nanofibrils (CNFs) used in this study were a commercial product, ARBOCEL MF40-10 at $10 \mathrm{wt} \%$ from J. Rettenmaier \& Söhne (JRS), Germany. The SEM images of CNFs are given in Fig. 1.

The CNFs were used to prepare the epoxy nanocomposites. A commercially available Technobond 3000 adhesive epoxy with two components, i.e., a resin and a hardener, was obtained from Techno Structural Chemicals, Turkey. The density of the epoxy adhesive was $1.15 \mathrm{~g} / \mathrm{cm}^{3}$. The flammable point of the epoxy was $180{ }^{\circ} \mathrm{C}$, and the curing time was $45 \mathrm{~min}$.

Different quantities (1\%, $2 \%$, and $3 \% \mathrm{wt})$ of cellulose nanofibrils were added to the epoxy resin, and the mixture was blended mechanically with a mechanical stirrer at $1500 \mathrm{rpm}$ for $20 \mathrm{~min}$ to obtain even

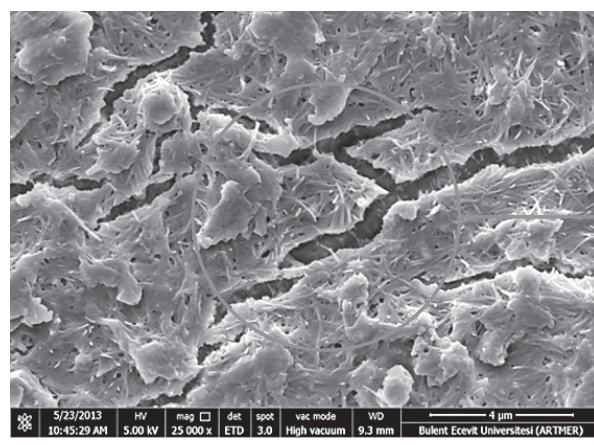

Figure 1 SEM images of cellulose nanofibrils Slika 1. SEM slike celuloznih nanofibrila 
dispersion. Then, an equal amount of hardener was added to the mixture, which was mixed mechanically again for $10 \mathrm{~min}$. The hardener was mixed homogenously throughout the adhesive by mechanical dispersion. An epoxy adhesive without cellulose nanofibrils was also prepared using equal amounts of resin and hardener, which were mixed mechanically until the mixture was homogeneous. The prepared adhesives were cast in aluminum molds, and the molds were cured for 1 day at $50{ }^{\circ} \mathrm{C}$ in an oven having $\pm 3{ }^{\circ} \mathrm{C}$ sensitivity and working without air circulation.

The morphology of the surfaces of the epoxy films was observed with an environmental scanning electron microscope (ESEM) (Phillips Electroscan 2020) with an accelerating voltage of $5 \mathrm{kV}$. The surfaces of all samples were sputter-coated with gold using a Denton sputter coater for enhanced conductivity. The thermal stability of the nanocomposites reinforced with cellulose nanofibrils was investigated using thermogravimetric analysis (TGA/DTG) (Perkin Elmer, TA Instruments, USA). The samples were heated from $25^{\circ} \mathrm{C}$ to $600{ }^{\circ} \mathrm{C}$ with a heating rate of $10{ }^{\circ} \mathrm{C} / \mathrm{min}$ and a nitrogen flow of $100 \mathrm{~mL} / \mathrm{min}$. The differential scanning calorimeter (DSC) tests were performed on a DSC 2920 (Perkin Elmer, TA Instruments, USA) at a heating rate of $5{ }^{\circ} \mathrm{C} / \mathrm{min}$ under a nitrogen atmosphere. The samples that were used weighed about $10 \mathrm{mg}$.

\section{RESULTS AND DISCUSSION}

\section{REZULTATI I RASPRAVA}

The SEM was an effective method for investigating the morphological characteristics of the composites. Fig. 2 shows the distribution of CNFs in the epoxy matrix. The SEM results showed that the CNFs were dispersed throughout the epoxy matrix. The dispersion of CNFs changed as the loading rates of the CNFs were increased from $1 \%$ to $3 \%$. Fig. 2 shows that clumping occurred for the $2 \%$ and $3 \%$ loadings of CNFs due to the strong affinity for hydrogen bonding or insufficient mixing. For the case of low loading, i.e., $1 \%$, the dispersion of CNFs was partially homogenous (Fig. 2a and $2 \mathrm{~b}$ ), but this condition was found to deteriorate as the loading was increased (Fig. 2c, 2d, 2e, and 2f). The poor dispersion can be said to occur due to increasing of viscosity. There were mechanically weak locations in the epoxy due to inadequate dispersion and poor bonding of the cellulose nanofibril domains. Therefore, the poor dispersion can be the cause of decreased mechanical performance.

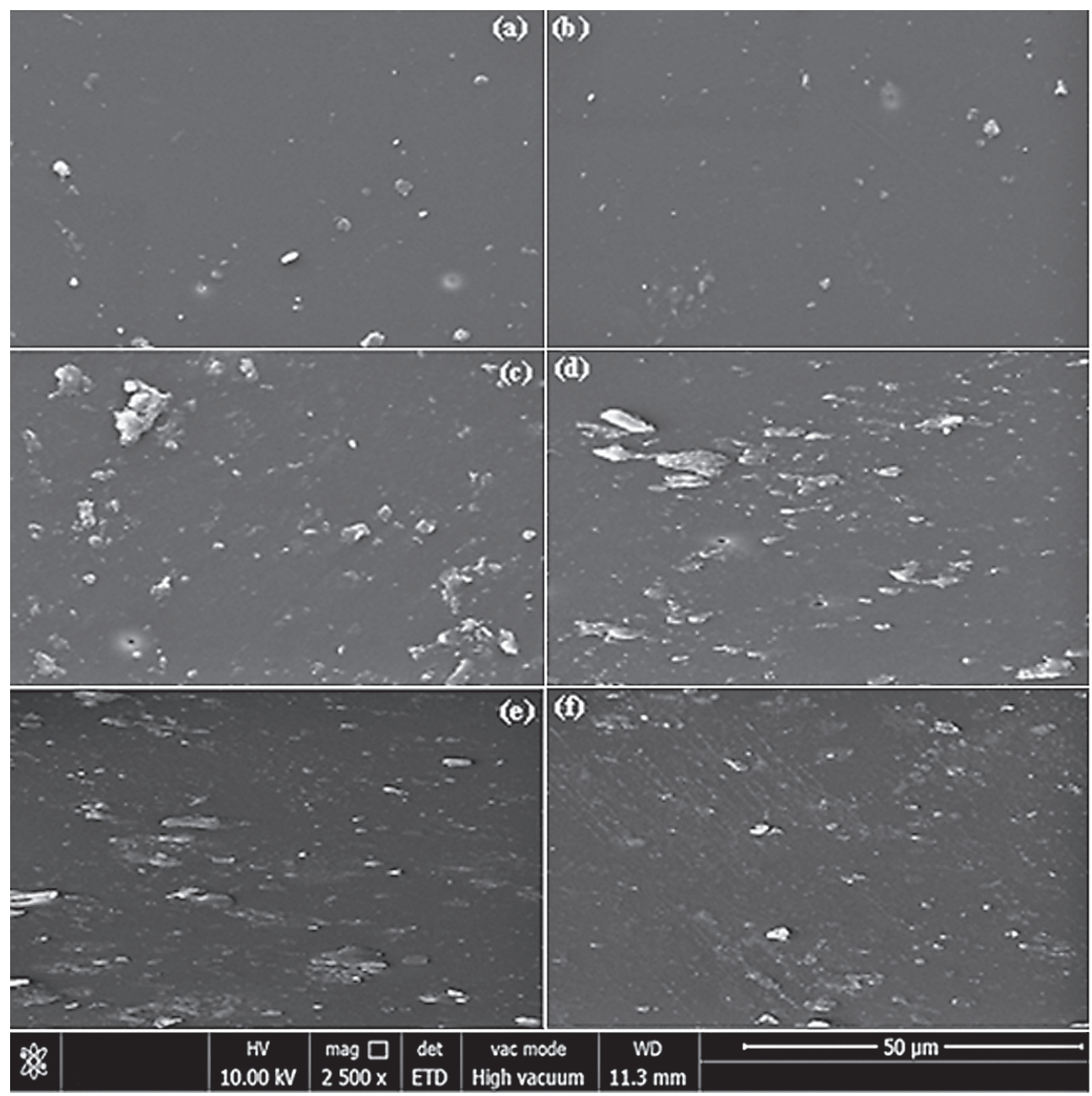

Figure 2 SEM images of cellulose nanofibrils reinforced epoxy nanocomposites: (a) and (b) $1 \%$ CNF; (c) and (d) $2 \%$ CNF; (e) and (f) $3 \%$ CNF

Slika 2. SEM slike epoksidnih nanokompozita ojačanih celuloznim nanofibrilima: a) i b) uz $1 \%$ CNFs-a; (c) i (d) uz 2 \% CNFs-a; (e) i (f) uz 3 \% CNFs-a 

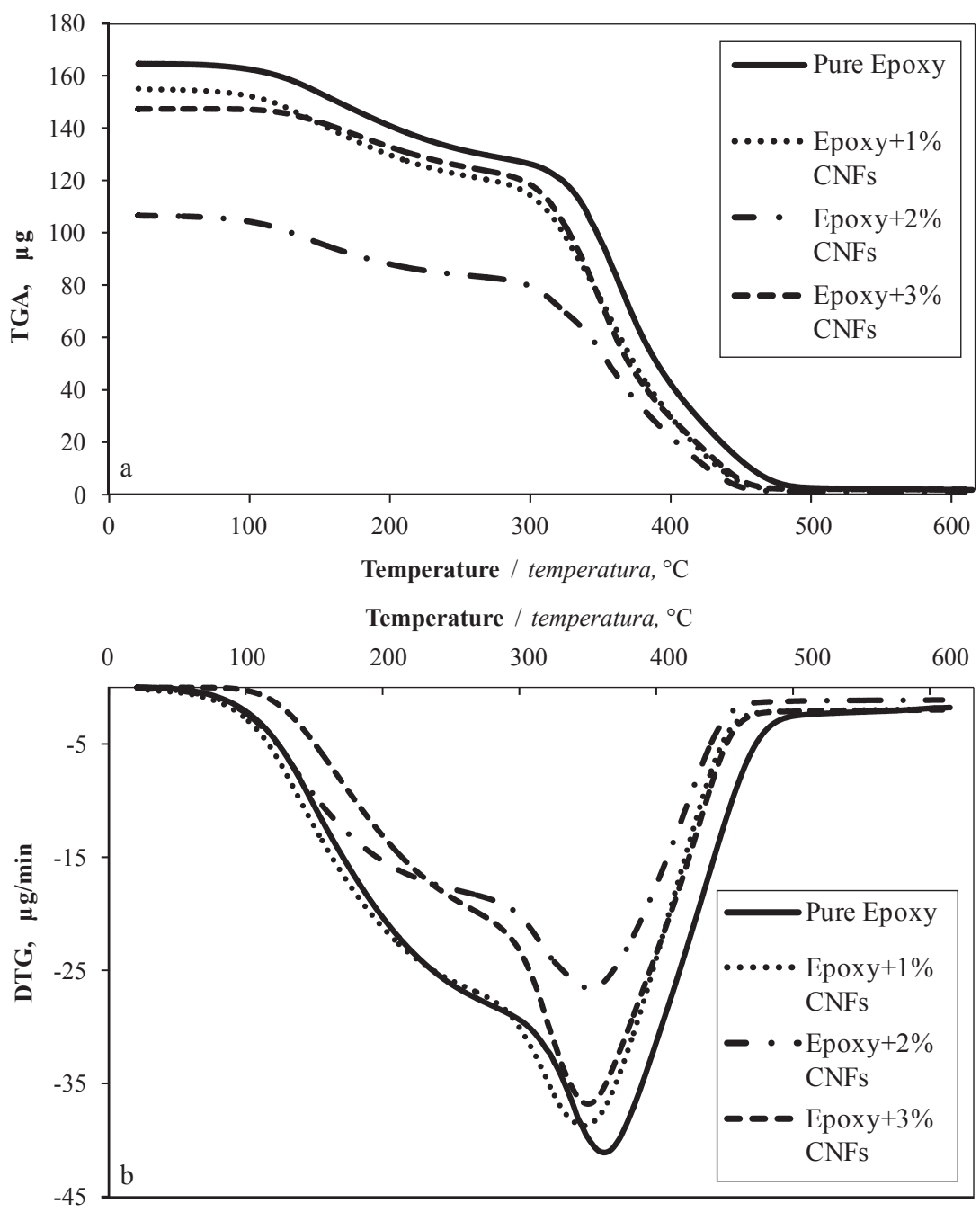

Figure 3 TG/DTG curves of CNF-reinforced epoxy nanocomposites

Slika 3. TG/DTG krivulje epoksidnih nanokompozita ojačanih celuloznim nanofibrilima

Lu et al. (2008) reported the surface modification of micro-fibrillated cellulose for epoxy composite applications. The SEM results showed that there was a non-uniform phase morphology that constituted many granular domains for all of the composites that were prepared. This was possibly because of poor mechanical mixing or faster cross-linking nature of the surface molecules, which formed a particulate structure (Nair and Dufresne, 2003).

Alamri and Low (2012) studied hybrid epoxy composites using cellulose and nano-SiC. The results showed that the dispersion of cellulose nanofibrils (1
$\%$ ) was essentially homogenous, but the dispersion for $3 \%$ was found to deteriorate, and many agglomerations were observed at this loading. Fig. 3 shows the thermal stability of the epoxy nanocomposites.

Three degradation steps for the samples were determined from the weight changes in TGA and the derivatives of the weight loss curves in Fig. 3a and Fig. $3 b$. At the first degradation point, pure epoxy and cellulosic nanocomposites exhibited mass losses due to the evaporation of moisture at around $50{ }^{\circ} \mathrm{C}$ to $100{ }^{\circ} \mathrm{C}$. Other decomposition points were determined in the DTG curves. A different decomposition point was

Table 1 Summary data of thermal stability of CNF-reinforced epoxy composites

Tablica 1. Sažeti podaci toplinske stabilnosti epoksidnih nanokompozita ojačanih celuloznim nanofibrilima

\begin{tabular}{|c|c|c|c|c|c|}
\hline \multirow{2}{*}{$\begin{array}{l}\text { Samples } \\
\text { Uzorci }\end{array}$} & \multirow{2}{*}{$\begin{array}{c}\text { DTG }_{\text {max }} \\
{ }^{\circ} \mathrm{C}\end{array}$} & \multirow{2}{*}{$\begin{array}{c}T_{10 \%} \\
{ }^{\circ} \mathrm{C}\end{array}$} & \multirow{2}{*}{$\begin{array}{c}\boldsymbol{T}_{50 \%} \\
{ }^{\circ} \mathrm{C}\end{array}$} & \multicolumn{2}{|c|}{$\begin{array}{c}\text { Maximum decomposition } \\
\text { Najveća dekompozicija }\end{array}$} \\
\hline & & & & $\begin{array}{c}\text { Residue / Ostatak } \\
\% / \mathrm{min}\end{array}$ & $\begin{array}{c}\text { Mass loss / Gubitak mase } \\
\%\end{array}$ \\
\hline Pure epoxy / čista epoksidna smola & 362.7 & 170.1 & 362.1 & 0.5 & 99.5 \\
\hline $1 \%$ CNF + epoxy / $1 \%$ CNF + epoksidna smola & 358.1 & 161.5 & 347.4 & 1.8 & 98.2 \\
\hline $2 \%$ CNF + epoxy / $2 \%$ CNF + epoksidna smola & 355.8 & 168.9 & 350.5 & 1.9 & 99.1 \\
\hline $3 \%$ CNF + epoxy / $3 \%$ CNF + epoksidna smola & 351.4 & 169.5 & 350.7 & 1.9 & 99.1 \\
\hline
\end{tabular}

Legend: DTG shows maximum degradation point of the composites; $T_{10 \%}$ and $T_{50 \%}$ show the degradation temperature at $10 \%$ and $50 \%$ weight losses, respectively. / Legenda: DTG $G_{\text {max }}$ pokazuje najveću temperaturu degradacije kompozita; $T_{10 \%}$ and $T_{50 \%}$ označava temperature degradacije pri gubitku mase od 10 i $50 \%$. 


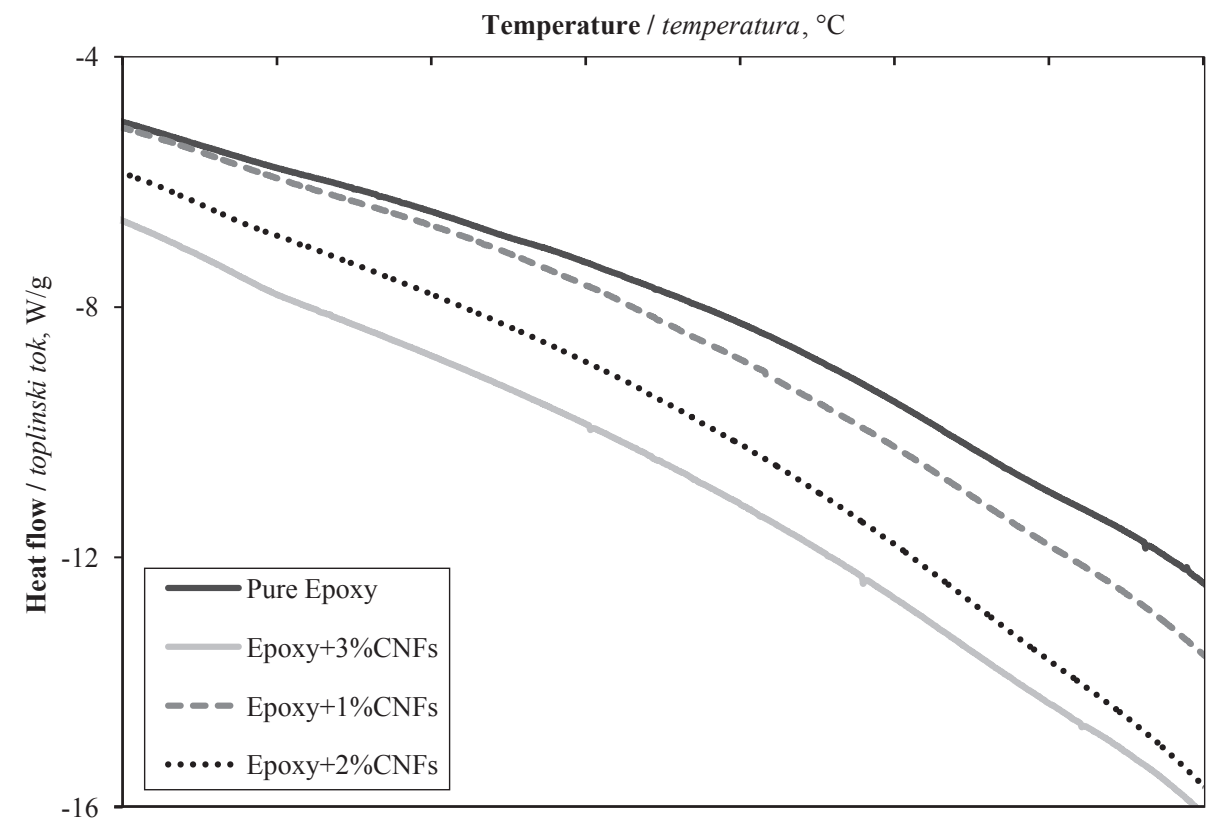

Figure 4 DSC curves of pure epoxy and cellulosic epoxy nanocomposites

Slika 4. DSC krivulje čiste epoksidne smole i celuloznih epoksidnih nanokompozita

found due to the presence of cellulose nanofibrils. The third point is shown at $T_{50 \%}$ (Tab. 1). DTG peaks showed that the peak and degradation temperatures of all composites were similar to that of pure epoxy. It was, however, found that the composites had shoulders ( $2^{\text {th }}$ degradation point between $150{ }^{\circ} \mathrm{C}$ and $250{ }^{\circ} \mathrm{C}$ ) in DTG curves due to the presence of CNFs.

It was found that the thermal stability of the composites was not improved by the addition of CNFs. When CNFs were added, the curves of $\mathrm{DTG}_{\max }$ (Tab. 1) were found to range from $362.7{ }^{\circ} \mathrm{C}$ to $351.4{ }^{\circ} \mathrm{C}$. The DTG values do not have a positive effect in raising the loading rate. The TGA curves decreased as the particle loadings increased. The highest residue of composites was found to be $1.9 \%$ for $2 \%$ and $3 \%$ additions of the cellulose nanofibrils. The maximum mass loss was calculated to be $99.5 \%$ for pure epoxy. Alamri and Low (2012) studied the thermal stability of epoxy nanocomposites. Their results showed that, at low temperatures $\left(<200{ }^{\circ} \mathrm{C}\right)$, epoxies with $1 \%$ and $2 \% \mathrm{CNFs}$ had better thermal stability than pure epoxy and those with $3 \%$ CNFs. Lu et al. (2008) worked with micro-fibrillated cellulose epoxy composites. The results showed that the decomposition of neat epoxy occurs between $325^{\circ} \mathrm{C}$ and $450{ }^{\circ} \mathrm{C}$, and the degradation of micro fibrillated cellulose (MFC) starts at $280^{\circ} \mathrm{C}$, which is lower than the temperature at which epoxy starts to degrade. Thus, the thermal stability of the composite was decreased slightly by the addition of $5 \% \mathrm{MFC}$, and MFC does not have any significant effect on the thermal stability of the resulting composite, although the residual weight following decomposition increased slightly. Fig. 4 shows DSC thermograms of the neat epoxy and the nanocomposites prepared with cellulose nanofibrils. The $T_{\mathrm{g}}$ values of the nanocomposites showed no appreciable changes among each other compared with their increase over neat epoxy. Isik et al. (2003) also observed that the glass transition temperatures of epoxy slightly increased with increasing clay content. This status explained this behavior in terms of the restricted mobility of polymer chains due to the interaction between the particles and the polymer.

\section{CONCLUSIONS \\ 4. ZAKLJUČAK}

The morphologies of epoxy nanocomposites that were prepared with cellulose nanofibrils were characterized and investigated for their thermal properties. The results showed that cellulose fibrils were found to have some effects on the morphological and thermal properties of epoxy. When the cellulose loading rate of nanofibrils in the epoxy was increased to $3 \%$, some clumping was observed on the SEM photographs. The thermal stability of epoxy was decreased by the addition of cellulose fibrils, and the highest $\mathrm{DTG}_{\max }$ was found at 362.7 ${ }^{\circ} \mathrm{C}$ for neat epoxy, whereas $\mathrm{DTG}_{\text {max }}$ was decreased to $351.4^{\circ} \mathrm{C}$ when the cellulose loading was increased.

\section{REFERENCES}

\section{LITERATURA}

1. Alamri, H.; Low, I. M., 2012: Characterization of epoxy hybrid composites filled with cellulose fibers and nanoSiC. Journal of Applied Polymer Science, 126(S1), E221-E231. http://dx.doi.org/10.1002/app.36815

2. Auer, S.; Frenkel, D., 2001: Suppression of crystal nucleation in polydisperse colloids due to increase of the surface free energy. Nature, 413(6857): 711-713. http://dx.doi.org/10.1038/35099513

3. Isik, I.; Yilmazer, U.; Bayram, G., 2003: Impact modified epoxy/montmorillonite nanocomposites: Synthesis and characterization. Polymer, 44(20): 6371-6377. http://dx.doi.org/10.1016/S0032-3861(03)00634-7

4. Kinloch, A. J.; Lee, J. H., 2003: Toughening structural adhesives via nano- and micro-phase inclusions. J. Adhes., 79(8/9): 867-873. http://dx.doi.org/10.1080/00218460390242234 
5. Kozma, L.; Olefjord, I., 1987: Surface treatment of steel for structural adhesive bonding. Mater. Sci. Technol., 3(11): 954-962.

http://dx.doi.org/10.1179/mst.1987.3.11.954

6. Lapique, F.; Redford, K., 2002: Curing effects on viscosity and mechanical properties of a commercial epoxy resin adhesive. Int. J. Adhes. Adhes., 22(4): 337-346. http://dx.doi.org/ 10.1016/S0143-7496(02)00013-1

7. Lu, J.; Askeland, P.; Drzal, L. T., 2008: Surface modification of microfibrillated cellulose for epoxy composite applications. Polymer, 49(5): 1285-1296. http://dx.doi.org/10.1016/j.polymer.2008.01.028

8. Masoodi, R.; El-Hajjar, R. F.; Pillai, K. M.; Sabo, V., 2012: Mechanical characterization of cellulose nanofiber and bio-based epoxy composite. Materials and Design, 36: $570-576$

http://dx.doi.org/10.1016/j.matdes.2011.11.042

9. Nair, K. G.; Dufresne, A., 2003: Crab shell chitin whisker reinforced natural rubber nanocomposites. 1. Processing and swelling behavior. Biomacromolecules, 4(3): 657665. http://dx.doi.org/10.1021/bm020127b

10. Petrie, E. M., 2006. Epoxy Adhesive Formulations, McGraw Hill, New York.

11. Sain, M.; Oksman, K., 2005: Introduction to Cellulose Nanocomposites, in: K. Oksman and M. Sain (Eds.), Washington, DC, ACS Symposium Series 938, p. 2.
12. Siro, I.; Plackett, D., 2010: Microfibrillated cellulose and new nanocomposite materials: A review. Cellulose, 17(3): 459-494.

http://dx.doi.org/10.1007/s10570-010-9405-y

13. Stewart, I.; Chambers, A.; Gordon, T., 2007: The cohesive mechanical properties of a toughened epoxy adhesive as a function of cure level. International Journal of Adhesion and Adhesives, 27(4): 277-287. http://dx.doi.org/10.1016/i.ijadhadh.2006.05.003

14. Zhai, L. L.; Ling, G. P.; Wang, Y. W., 2007: Effect of nano- $\mathrm{Al}_{2} \mathrm{O}_{3}$ on adhesion strength of epoxy adhesive and steel: International Journal of Adhesion \& Adhesives, 28(1): 23-28.

http://dx.doi.org/10.1016/j.jjadhadh.2007.03.005

\section{Corresponding address:}

Assist. Prof. DENIZ AYDEMIR, Ph. D.

\section{Bartin University}

Faculty of Forestry, Forest Industrial Engineering 74100, Bartin, TURKEY

e-mail: denizoren32@yahoo.co.uk 